\title{
Characterization of the effects of $\mathrm{Ca}^{2+}$ depletion on the synthesis, phosphorylation and secretion of caseins in lactating mammary epithelial cells
}

\author{
Jennifer S. DUNCAN and Robert D. BURGOYNE* \\ The Physiological Laboratory, University of Liverpool, Crown Street, Liverpool L69 3BX, U.K.
}

\begin{abstract}
We have examined the effects of depleting lumenal $\mathrm{Ca}^{2+}$ on the synthesis, phosphorylation and secretion of caseins in lactating mouse mammary cells by using inhibitors of the endoplasmic reticulum $\mathrm{Ca}^{2+}$-ATPase or the ionophore ionomycin in the absence of external $\mathrm{Ca}^{2+}$. Treatment with these drugs resulted in a transient increase in the cytosolic $\mathrm{Ca}^{2+}$ concentration due to $\mathrm{Ca}^{2+}$ mobilization. Protein synthesis over a $1 \mathrm{~h}$ period was substantially inhibited by $\mathrm{Ca}^{2+}$ depletion, but in a pulse-chase protocol secretion of pre-synthesized proteins was unaffected by $\mathrm{Ca}^{2+}$ depletion. Analysis of polysome profiles showed that $\mathrm{Ca}^{2+}$ depletion resulted in a loss in polysomes, consistent with an
\end{abstract}

inhibition of initiation of protein synthesis. Neither treatment with $\mathrm{Ca}^{2+}$-ATPase inhibitors to deplete endoplasmic reticulum $\mathrm{Ca}^{2+}$ nor treatment with ionomycin/EGTA had any effect on an early phase of phosphorylation of $\alpha$ - or $\beta / \gamma$-caseins, but $\mathrm{Ca}^{2+}$ depletion resulted in a decrease in a late phase of casein phosphorylation. These results indicate that lumenal $\mathrm{Ca}^{2+}$ is required to maintain protein synthesis in lactating mammary cells but is not required for protein secretion, and that $\mathrm{Ca}^{2+}$ accumulation in the Golgi cisternae is required for a late but not for an early phase of casein phosphorylation.

\section{INTRODUCTION}

Cytosolic free $\mathrm{Ca}^{2+}$ is required for vesicular transport between the endoplasmic reticulum (ER) and the Golgi complex and between compartments of the Golgi complex [1], as well as stimulating regulated exocytosis in many cell types [2]. $\mathrm{Ca}^{2+}$ within the lumen of the ER and possibly the Golgi cisternae has additional roles in the secretory pathway [3]. The ER accumulates $\mathrm{Ca}^{2+}$ to high levels due to the action of a $\mathrm{Ca}^{2+}$-ATPase [4], and high levels of $\mathrm{Ca}^{2+}$ within the Golgi cisternae have also been observed [5]. Depletion of $\mathrm{Ca}^{2+}$ from these intracellular organelles has several effects on the secretory pathway, including inhibition of protein synthesis at the level of translation [6,7] following phosphorylation of initiation factor $2[8,9]$, acceleration of protein degradation within the ER [10], increased secretion of resident ER proteins [11], decreased processing of $\mathrm{N}$-linked oligosaccharides on $\alpha_{1}$-antitrypsin and decreased secretion of the latter (but not of albumin) from HepG2 cells [7], and inhibition of brefeldin A-induced retrograde transport from the Golgi complex to the ER [12]. These effects have been demonstrated by removal of external $\mathrm{Ca}^{2+}$ and treatment with $\mathrm{Ca}^{2+}$ ionophores, or more specifically with inhibitors of the organellar, particularly $\mathrm{ER}, \mathrm{Ca}^{2+}$-ATPases. It has been established that these disruptions of the secretory pathway are not a consequence of $\mathrm{Ca}^{2+}$ release into the cytoplasm and the subsequent increase in the cytosolic $\mathrm{Ca}^{2+}$ concentration, but are due to depletion of lumenal $\mathrm{Ca}^{2+}$. It is believed, therefore, that $\mathrm{Ca}^{2+}$ within the ER and/or the Golgi plays an important role in the control of the folding and stability of nascent proteins, and in protein interactions within these organelles, and thereby controls the processing and traffic of secretory proteins.

Lactating mammary epithelial cells possess $\operatorname{Ins}(1,4,5) P_{3}$-sensitive $\mathrm{Ca}^{2+}$ stores [13]. $\mathrm{Ca}^{2+}$ uptake and the presence of $\mathrm{Ca}^{2+}$ ATPase activity has been demonstrated in both ER and Golgi vesicles derived from these cells [14-17]. $\mathrm{Ca}^{2+}$ accumulation into these organelles is required to allow substantial secretion of $\mathrm{Ca}^{2+}$ along with lactose and caseins during the exocytosis of casein vesicles to provide the high level of $\mathrm{Ca}^{2+}$ (up to $100 \mathrm{mM}$ ) found in milk. In addition, calcium phosphate has been shown to be required for the formation and stability of the typical casein micelle structure, which is essentially due to $\mathrm{Ca}^{2+}$-dependent aggregation of the caseins following their phosphorylation $[18,19]$. It is not clear whether intralumenal $\mathrm{Ca}^{2+}$ is required for casein stability prior to secretion or for casein phosphorylation in vivo, which occurs in the Golgi complex [20-23]. A number of other secretory proteins have been found to be phosphorylated during their passage through the secretory pathway, including progastrin [24] and the chromogranins [25], but the requirement for lumenal $\mathrm{Ca}^{2+}$ for phosphorylation of these proteins has not been examined. Casein kinase activity in vitro is cation dependent and is stimulated by $\mathrm{Ca}^{2+}$, but $\mathrm{Mg}^{2+}$ is as effective as $\mathrm{Ca}^{2+}$ and $\mathrm{Mn}^{2+}$ is yet more effective [23,26,27], and so the requirement for lumenal $\mathrm{Ca}^{2+}$ for casein phosphorylation in vivo is unclear. We show here that depletion of intracellular $\mathrm{Ca}^{2+}$ stores by treatment with $\mathrm{Ca}^{2+}$-ATPase inhibitors or the $\mathrm{Ca}^{2+}$ ionophore ionomycin inhibits protein synthesis in lactating mouse mammary cells but has no effect on the secretion of the major milk caseins. The phosphorylation of the caseins occurs in two phases, and $\mathrm{Ca}^{2+}$ depletion inhibited the late but not the early phase of casein phosphorylation.

\section{MATERIALS AND METHODS}

\section{Materials}

Ionomycin was purchased from Calbiochem-Novabiochem, Nottingham, U.K., and 2,5-di-(t-butyl)-1,4-benzohydroquinone (tBHQ) was a gift from Dr. C. W. Taylor (University of Cambridge, U.K). Unless otherwise stated, tissue culture media were obtained from Gibco BRL Life Technologies Ltd., Paisley, 
Scotland, U.K., and other reagents were from Sigma Chemical Co., Poole, Dorset, U.K.

\section{Cell preparation}

Mammary glands were dissected from mid-lactation (day 10-11) primigravida Tuck's no. 1 mice. The tissue was digested into acini of $10-30$ cells by incubation with $0.14 \%$ collagenase (Lorne Laboratories, Twyford, Berks., U.K.) in Hanks balanced salt solution containing $5 \mu \mathrm{g} / \mathrm{ml}$ insulin and $0.01 \mu \mathrm{g} / \mathrm{ml}$ cortisol. The digestion was terminated when the cell suspension was filtered through a $150 \mu \mathrm{m}$ pore nylon mesh, and the cells were washed by centrifugation and resuspension in a medium containing $0.1 \mathrm{mg} / \mathrm{ml}$ trypsin inhibitor, $0.04 \mathrm{mg} / \mathrm{ml} \mathrm{DNase} \mathrm{I} \mathrm{(Boehringer}$ Mannheim), $5 \mu \mathrm{g} / \mathrm{ml}$ insulin and $0.01 \mu \mathrm{g} / \mathrm{ml}$ cortisol. The cell suspension was then filtered through a $53 \mu \mathrm{m}$ pore nylon mesh, washed again and finally resuspended in culture medium $[0.1 \mu \mathrm{g} / \mathrm{ml}$ prolactin, $0.01 \mu \mathrm{g} / \mathrm{ml}$ epidermal growth factor, $0.001 \mu \mathrm{g} / \mathrm{ml}$ tri-iodothyronine, $5 \mu \mathrm{g} / \mathrm{ml}$ insulin, $0.01 \mu \mathrm{g} / \mathrm{ml}$ cortisol, $50 \%$ (v/v) M199 medium, 50\% (v/v) Ham's F12, $2.5 \%$ $(\mathrm{w} / \mathrm{v}) \mathrm{BSA}$. The cells were then counted using a haemocytometer and diluted to a final concentration of $1 \times 10^{6}$ cells per $\mathrm{ml}$ of culture medium. Cell viability was assessed by Trypan Blue exclusion and was around $90-95 \%$.

\section{Measurement of protein synthesis and secretion}

To study protein synthesis or secretion [28,29], the cells at $1 \times 10^{6}$ were incubated ( $1 \mathrm{ml}$ per incubation) for $1 \mathrm{~h}$ at $37^{\circ} \mathrm{C}$ in an atmosphere containing $5 \% \mathrm{CO}_{2}$ and $95 \% \mathrm{O}_{2}$ with $10 \mu \mathrm{Ci} / \mathrm{ml}$ L- $\left[{ }^{35}\right.$ S]methionine (cell labelling grade; specific radioactivity $>13000 \mathrm{Ci} / \mathrm{mmol}$; Amersham International).

For assay of protein synthesis over this time, the cells were incubated in the presence or absence of drugs and the incubations were terminated by centrifugation of the suspended cells for $1 \mathrm{~min}$ in a Microfuge at $2500 \mathrm{~g}$. The cell pellets were mixed with $100 \mu \mathrm{l}$ of $1 \%$ (w/v) BSA and $800 \mu \mathrm{l}$ of $10 \%$ (w/v) trichloroacetic acid and left for $1 \mathrm{~h}$ at $4{ }^{\circ} \mathrm{C}$. The precipitated protein was extracted by centrifugation in a Microfuge at $2500 \mathrm{~g}$ for $1 \mathrm{~min}$ and then washed twice in $10 \%$ trichloroacetic acid. The final pellets were mixed with $10 \mathrm{ml}$ of Cocktail $\mathrm{T}(\mathrm{BDH})$ and the incorporated ${ }^{35} \mathrm{~S}$ was determined by scintillation counting.

For assay of protein secretion, cells labelled for $1 \mathrm{~h}$ in the absence of drug additions were chased for a further $1 \mathrm{~h}$ in medium lacking radiolabel in the absence or presence of added drugs. After centrifugation, duplicate aliquots of the supernatants were mixed with equal volumes of $20 \%$ trichloroacetic acid, the trichloroacetic acid precipitates were washed and ${ }^{35} \mathrm{~S}$ in secreted proteins was determined by scintillation counting. The extent of secretion of radiolabelled proteins was calculated and expressed as a percentage of total label incorporated.

\section{Analysis of casein phosphorylation}

Cells at $1 \times 10^{6}$ per $\mathrm{ml}$ were incubated $(1 \mathrm{ml}$ per incubation) with $75 \mu \mathrm{Ci} / \mathrm{ml}\left[{ }^{32} \mathrm{P}\right] \mathrm{P}_{\mathrm{i}}$ (Amersham) and $100 \mu \mathrm{g} / \mathrm{ml}$ cycloheximide, with or without thapsigargin $(1 \mu \mathrm{M})$ or ionomycin $(10 \mu \mathrm{M})+2 \mathrm{mM}$ EGTA for $30 \mathrm{~min}$. The cells were then sedimented by centrifugation for $15 \mathrm{~s}$ at $2500 \mathrm{~g}$, and the cell pellets from the duplicate incubations were resuspended, pooled and washed once in PBS before resuspension in $100 \mu \mathrm{l}$ of SDS dissociation buffer and boiling for $5 \mathrm{~min}$. The samples were separated in duplicate by SDS/PAGE (12.5.\% gels) along with molecular mass markers and mouse casein standards. The gels were stained with Coomassie Brilliant Blue before drying on a Bio-Rad Slab Gel Drier and exposing them to a Molecular
Dynamics PhosphorScreen and processing using a PhosphorImager (Molecular Dynamics). The images were quantified using Image Quant software (Molecular Dynamics). For each determination, three aliquots of labelled cells were pooled and analysed on duplicate gels to produce a mean value. In each experiment six independent values were determined in this way for control and experimental conditions.

\section{Polysome profile}

Cells $\left(1 \times 10^{6}\right.$ per $\left.\mathrm{ml}\right)$ were incubated for $1 \mathrm{~h}$ in the presence or absence of drug additions under the conditions described above. A $15 \mathrm{ml}$ sample of the cell suspension was then centrifuged at $80 \mathrm{~g}$ for $3 \mathrm{~min}$ and the cell pellet resuspended in $0.9 \mathrm{ml}$ of lysis buffer (50 mM Tris, $\mathrm{pH} 7.4,26 \mathrm{mM} \mathrm{KCl}, 5 \mathrm{mM} \mathrm{MgCl}{ }_{2}$, $1 \%$ Triton $\mathrm{X}-100,1 \%$ sodium deoxycholate, $1 \mathrm{mg} / \mathrm{ml}$ heparin, $10 \mu \mathrm{g} / \mathrm{ml}$ cycloheximide), before centrifugation at $10000 \mathrm{~g}$ for $10 \mathrm{~min}$ at $4{ }^{\circ} \mathrm{C}$. Aliquots of the supernatants $(300 \mu \mathrm{l})$ were applied to $13 \mathrm{ml}$ sucrose gradients. The gradients were formed of $17-51 \%$ (w/v) sucrose in $50 \mathrm{mM}$ Tris, $\mathrm{pH} 7.4,25 \mathrm{mM} \mathrm{KCl,} 5 \mathrm{mM} \mathrm{MgCl}_{2}$ and were prepared using an Autodensiflow IIC gradient fractionator (Buchler Instruments). The gradients were centrifuged for $2 \mathrm{~h}$ at $270000 \mathrm{~g}$ at $4{ }^{\circ} \mathrm{C}$, and then analysed by extraction by the Autodensiflow IIC gradient fractionator and pumped through a Monitor UV-M (Pharmacia LKB Biotechnology, Uppsala, Sweden); absorbance was monitored at $254 \mathrm{~nm}$.

\section{Measurement of cytosolic free $\mathrm{Ca}^{2+}$ concentration}

Mammary acini at a density of $1 \times 10^{6}$ cells per $\mathrm{ml}$ were suspended in a buffer containing $145 \mathrm{mM} \mathrm{NaCl}, 5 \mathrm{mM} \mathrm{KCl}, 1.2 \mathrm{mM}$ $\mathrm{NaH}_{2} \mathrm{PO}_{4}, 10 \mathrm{mM}$ glucose, $20 \mathrm{mM}$ Hepes, $0.78 \mathrm{mM} \mathrm{CaCl}$, $1.3 \mathrm{mM} \mathrm{MgCl} 2$ and $0.5 \% \mathrm{BSA}, \mathrm{pH} 7.4$. The cell suspension was incubated at room temperature for 45 min with $10 \mu \mathrm{M}$ fura2/AM, washed twice in fresh buffer, incubated for a further $45 \mathrm{~min}$ at $37^{\circ} \mathrm{C}$, and washed three times before resuspension in fresh buffer at $37^{\circ} \mathrm{C}$. Fluorescence was measured using an LS5 Luminescence Spectrophotometer (Perkin-Elmer Corp., Norwalk, CT, U.S.A.). Excitation wavelengths were $340 \mathrm{~nm}$ and $380 \mathrm{~nm}$, the emission wavelength was $509 \mathrm{~nm}$ and values for the ratio of emission at $380 / 340 \mathrm{~nm}(R)$ were determined. The fluorescence was calibrated by cell lysis with $200 \mu \mathrm{M}$ digitonin followed by chelation using $40 \mathrm{mM}$ EGTA. The $\mathrm{Ca}^{2+}$ concentration $\left(\left[\mathrm{Ca}^{2+}\right]_{\mathrm{i}}\right)$ was calculated by determining emission ratios $(R)$ at basal (EGTA) and peak (digitonin) $\mathrm{Ca}^{2+}$ levels and substituting the values for $R$ at each time point into the following formula:

$\left[\mathrm{Ca}^{2+}\right]_{\mathrm{i}}=873 \times(R-105) /(19.5-R)$

\section{RESULTS}

This study was carried out with freshly isolated acini from lactating mouse mammary glands. These mammary cells have been extensively characterized and shown to remain polarized, viable and active in protein synthesis and secretion over several hours [28-30]. Protein secretion into the medium is temperatureand microtubule-dependent [29]. The predominant proteins synthesized and secreted by these cells are the secretory milk proteins, which are mainly $\alpha-, \beta$ - and other caseins [28-30]. Assay of $\left[{ }^{35} \mathrm{~S}\right]$ methionine incorporation into total cellular protein or into proteins released into the medium, therefore, provides a reliable estimate of casein synthesis and secretion.

The approaches used in this study to deplete lumenal $\mathrm{Ca}^{2+}$ used the $\mathrm{Ca}^{2+}$-ATPase inhibitors thapsigargin [31] and tBHQ [32] or treatment with the $\mathrm{Ca}^{2+}$ ionophore ionomycin in the absence 

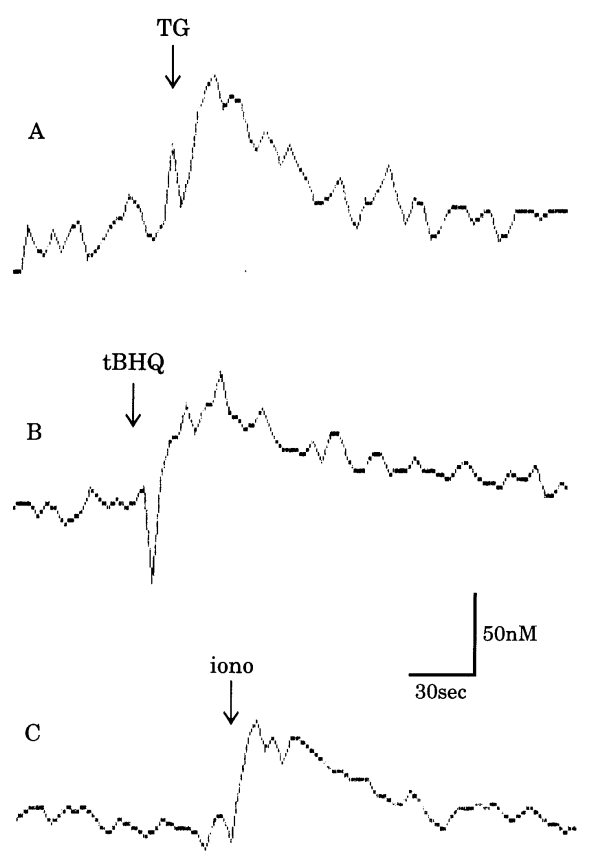

Figure 1 Changes in cytosolic $\mathrm{Ca}^{2+}$ concentration in lactating mouse mammary cells in response to thapsigargin, $\mathrm{tBHQ}$ or ionomycin

Isolated acini from lactating mouse mammary glands were loaded with the $\mathrm{Ca}^{2+}$ indicator fura2 and challenged with $1 \mu \mathrm{M}$ thapsigargin (TG) $(\mathbf{A})$ or $100 \mu \mathrm{M}$ tBHQ $(\mathbf{B})$ in the presence of external $\mathrm{Ca}^{2+}$, or with $10 \mu \mathrm{M}$ ionomycin (iono) plus $2 \mathrm{mM}$ EGTA to chelate external $\mathrm{Ca}^{2+}$ (C).

of external $\mathrm{Ca}^{2+}$. All three treatments led to a burst of $\mathrm{Ca}^{2+}$ mobilization, seen as a transient rise in the cytosolic $\mathrm{Ca}^{2+}$ concentration detectable with the $\mathrm{Ca}^{2+}$ indicator fura-2 (Figure 1). Ionomycin in the absence of external $\mathrm{Ca}^{2+}$ would be expected to deplete all internal lumenal $\mathrm{Ca}^{2+}$ stores, whereas the $\mathrm{Ca}^{2+}$ ATPase inhibitors are expected to be specific for the ER (although no data are available on the potential sensitivity of any Golgi ATPase to these drugs). The mean peak rises in cytosolic $\mathrm{Ca}^{2+}$ concentration were $98.2 \pm 17.0 \mathrm{nM}(n=7), 118.8 \pm 17.0 \mathrm{nM}$ $(n=8)$ and $43.5 \pm 8.4 \mathrm{nM}(n=4)$ above basal levels for $1 \mu \mathrm{M}$ thapsigargin, $100 \mu \mathrm{M}$ tBHQ and $10 \mu \mathrm{M}$ ionomycin respectively. Lower concentrations of thapsigargin (100 $\mathrm{nM}$ or less) did not produce detectable rises in the cytosolic $\mathrm{Ca}^{2+}$ concentration.

The effect of $\mathrm{Ca}^{2+}$ depletion on protein synthesis was assayed by examining the effect of the drugs during a $1 \mathrm{~h}$ labelling period with $\left[{ }^{35}\right.$ S $]$ methionine. The effect on secretion was assayed by pulse-labelling the cells for $1 \mathrm{~h}$ and then following secretion over a subsequent $1 \mathrm{~h}$ chase period in the presence or absence of drugs. These conditions were chosen based on previous work on isolated lactating mouse mammary cells which showed that little secretion occurs over the $1 \mathrm{~h}$ pulse-labelling period and that constitutive secretion of caseins is essentially complete over a $1 \mathrm{~h}$ chase period [28-30]. Thapsigargin at concentrations up to $1 \mu \mathrm{M}$ produced a dose-dependent inhibition of synthesis in mammary cells, but had no effect on protein secretion (Figure 2A). Similar results were seen with five different batches of cells, with a maximal inhibition of protein synthesis of $60 \pm 5.5 \%(n=5)$ at $1 \mu \mathrm{M}$ thapsigargin. On SDS/PAGE and fluorography this was seen as a general reduction of labelling of all synthesized polypeptides, which are mainly caseins (Figure 2C). To confirm that this effect was due to the inhibition of the ER $\mathrm{Ca}^{2+}$-ATPase activity, the effect of the structurally unrelated $\mathrm{Ca}^{2+}$-ATPase inhibitor $\mathrm{BH} \mathrm{Q}$ was examined. This drug also produced a marked
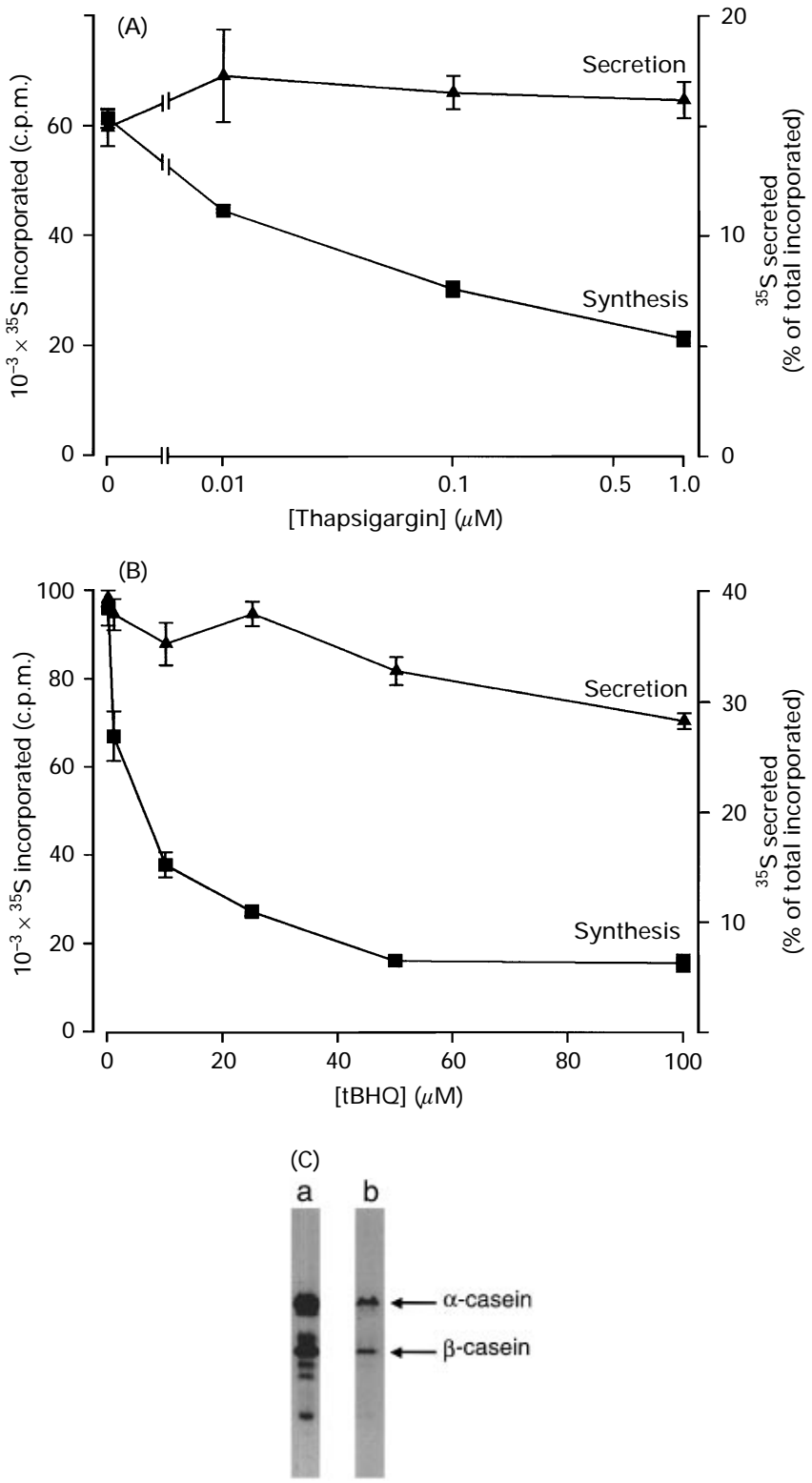

Figure 2 Effects of thapsigargin and $\mathrm{tBHQ}$ on protein synthesis and secretion in lactating mouse mammary cells

Isolated acini from lactating mouse mammary glands were incubated with $\left[{ }^{35} \mathrm{~S}\right]$ methionine for $1 \mathrm{~h}$ in the absence or presence of the indicated concentrations of thapsigargin $(\mathbf{A})$ or $\mathrm{ABHQ}(\mathbf{B})$, and the extent of protein synthesis over this period was determined from the incorporation into total cellular trichloroacetic acid-precipitable protein. Separate batches of cells were radiolabelled for $1 \mathrm{~h}$, washed and then incubated for $1 \mathrm{~h}$ without or with added thapsigargin or tBHQ. The extent of secretion over the chase period was determined from the level of radiolabelled trichloroacetic acid-precipitable protein present in the medium and expressed as a percentage of the total incorporation of radiolabel $(n=4)$. (C) SDS/PAGE and Phosphorlmager analysis of $\left[{ }^{35}\right.$ S]methionine incorporation into control cells (lane a) and cells treated with $1 \mu \mathrm{M}$ thapsigargin (lane b).

inhibition of protein synthesis (Figure 2B), with relatively little effect on protein secretion except at high concentrations $(100 \mu \mathrm{M})$ that were already maximal for inhibition of protein synthesis. Similar results were found with $\mathrm{tBHQ}$ in two separate batches of cells, with maximal inhibition of 84 and $52 \%$ at $100 \mu \mathrm{M}$ tBHQ in the two experiments. The data on the effect of thapsigargin on protein secretion shown in Figure 2(A) were based on exam- 


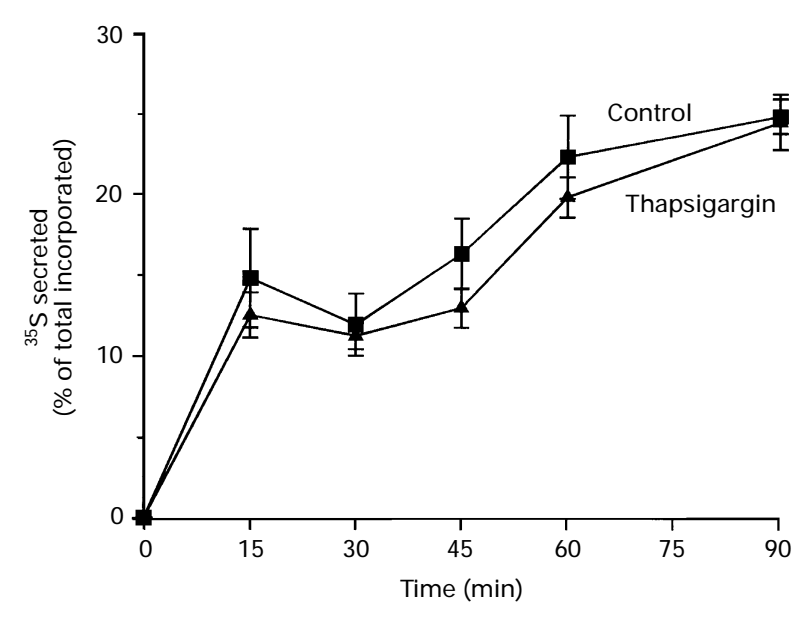

Figure 3 Effect of thapsigargin on the time course of protein secretion in lactating mouse mammary cells

Isolated acini from lactating mouse mammary glands were pulse-labelled with $\left[{ }^{35} \mathrm{~S}\right]$ methionine for $1 \mathrm{~h}$, washed and then protein secretion was monitored during the chase periods from analysis of incorporation into trichloroacetic acid-precipitable protein released into the medium. The cells were incubated during the chase period without (control) or with $1 \mu \mathrm{M}$ thapsigargin. Data shown are means \pm S.E.M. $(n=4)$.

ination of a single time point $(1 \mathrm{~h})$. In order to examine possible effects of thapsigargin on the rate of secretion, the time course of protein secretion in the absence or presence of $1 \mu \mathrm{M}$ thapsigargin was examined. No inhibitory effects of thapsigargin on protein secretion were seen at any time point (Figure 3 ).

We have previously demonstrated that treatment of mammary cells with the $\mathrm{Ca}^{2+}$ ionophore ionomycin also results in inhibition of protein synthesis [28]. These earlier experiments were carried out with external $\mathrm{Ca}^{2+}$ present and could have been due to sustained elevation of cytosolic $\mathrm{Ca}^{2+}$ due to $\mathrm{Ca}^{2+}$ entry rather than lumenal $\mathrm{Ca}^{2+}$ depletion. To avoid problems of interpretation, the effects of ionomycin in the presence of $2 \mathrm{mM}$ EGTA, to deplete external $\mathrm{Ca}^{2+}$ and thus prevent external $\mathrm{Ca}^{2+}$ entry, were examined. Under these conditions, where the sustained effect of ionomycin should be solely due to depletion of lumenal $\mathrm{Ca}^{2+}, 10 \mu \mathrm{M}$ ionomycin produced a $61 \pm 1.5 \%(n=4)$ inhibition of protein synthesis in the lactating mammary cells.

Depletion of lumenal $\mathrm{Ca}^{2+}$ has been shown in other cell types to inhibit translation, and this can be seen as a reduction in polysome content and an increase in $80 \mathrm{~S}$ monosomes in analyses of polysomal profiles using density gradients. Such a loss of polysomes and an increase in the size of the $80 \mathrm{~S}$ monosome peak were seen following treatment of lactating mammary cells with $1 \mu \mathrm{M}$ thapsigargin or $100 \mu \mathrm{M}$ tBHQ for $1 \mathrm{~h}$ (Figure 4). The traces shown are representative of five gradients each for control and thapsigargin treatment and three each for experiments with tBHQ.

Having established that treatment with $\mathrm{Ca}^{2+}$-ATPase inhibitors or with ionomycin in the absence of external $\mathrm{Ca}^{2+}$ leads to release of lumenal $\mathrm{Ca}^{2+}$ and inhibition of protein synthesis, we examined the effects of these drugs on casein phosphorylation by following ${ }^{32} \mathrm{P}$ incorporation into $\alpha-, \beta$ - and $\gamma$-caseins. The caseins are the major phosphoproteins synthesized in lactating mammary cells [22]. Since the treatments inhibit protein synthesis, this would reduce the amount of caseins available for phosphorylation. In order to remove differences between treatments, all cells were treated with $100 \mu \mathrm{g} / \mathrm{ml}$ cycloheximide at the time of drug addition to ensure that only phosphorylation of pre-synthesized caseins
A

C

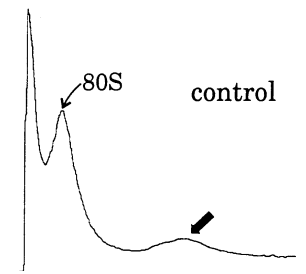

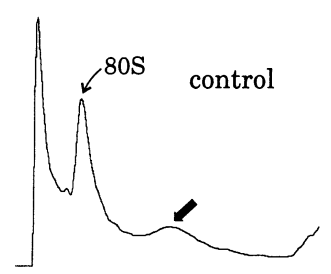
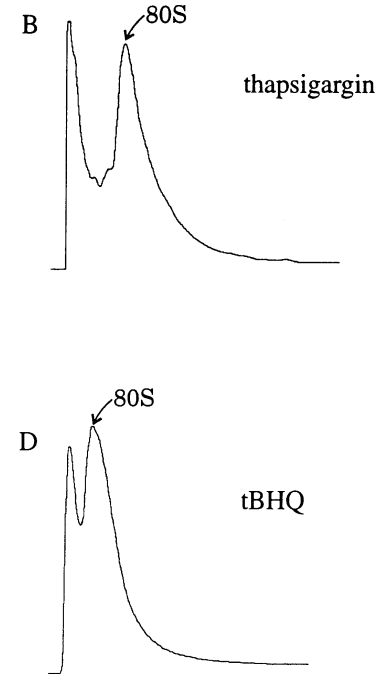

Figure 4 Effects of thapsigargin and tBHQ on polysome profiles in lactating mouse mammary cells

Isolated acini from lactating mouse mammary glands were incubated for $1 \mathrm{~h}$ under control conditions (A, C) or with the addition of $1 \mu \mathrm{M}$ thapsigargin (B) or $100 \mu \mathrm{M} \mathrm{tBHQ}$ (D) in two separate experiments. Cell extracts were separated on sucrose gradients to examine the polysome/monosome profile. The position of the $80 \mathrm{~S}$ monosome peak is indicated, and the polysome peak in control cells is shown by the thick arrow.

was monitored. Cycloheximide at this concentration inhibited protein synthesis by $93 \% . \beta$ - and $\gamma$-caseins migrated close to each other (Figure 5) and were quantified together. In previous work, a phase of casein phosphorylation was observed that was complete within 20-30 min [23]. In initial experiments, therefore, we examined the effect of thapsigargin on the extent of casein phosphorylation following a $30 \mathrm{~min}$ incubation (Figure 5). Under these conditions no effect of thapsigargin on casein phosphorylation was detected in six experiments. It is not known whether thapsigargin would act on $\mathrm{Ca}^{2+}$ transport within the Golgi in addition to its effects on the ER, and so we also examined the effect of $\mathrm{Ca}^{2+}$ depletion using ionomycin in the presence of EGTA, which would be expected to deplete $\mathrm{Ca}^{2+}$ from all cellular organelles. In addition, the time course of casein phosphorylation in the absence and presence of ionomycin/ EGTA was followed for up to $3 \mathrm{~h}$. Over a short time course (Figures 6A and 6B), it was apparent that there was an early phase of casein phosphorylation over the first 30 min that was essentially unaffected by $\mathrm{Ca}^{2+}$ depletion. The rate of casein phosphorylation then increased, and in experiments over a longer time course the later phase of casein phosphorylation was found to continue for up to $150 \mathrm{~min}$ (Figures 6C and 6D). The second phase of casein phosphorylation was partially inhibited by $\mathrm{Ca}^{2+}$ depletion using ionomycin/EGTA and reached a new lower plateau of phosphorylation after incubation for $150 \mathrm{~min}$ (Figures 6C and 6D). Similar results were seen for $\alpha$-casein (Figures 6A and $6 \mathrm{C}$ ) and for $\beta / \gamma$-caseins (Figures $6 \mathrm{~B}$ and $6 \mathrm{D}$ ).

The time course of casein phosphorylation seen in these experiments was slow compared with the transit times (45$60 \mathrm{~min}$ ) previously found for newly synthesized casein to pass through the secretory pathway and be constitutively secreted $[28,29]$. It should be noted, however, that a portion of newly synthesized casein is not secreted, but instead accumulates in a regulated exocytotic compartment [28]. Since these phosphorylation experiments were carried out on cycloheximide-treated 


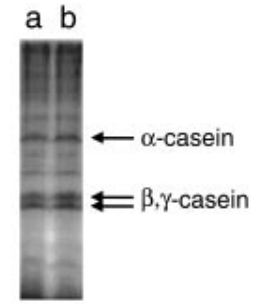

Figure 5 SDS/polyacrylamide gel analysis of proteins phosphorylated in lactating mouse mammary cells in the absence or presence of thapsigargin

Isolated acini from lactating mouse mammary glands were incubated with $\left[{ }^{32} \mathrm{P}\right] \mathrm{P}_{\mathrm{i}}$ for $30 \mathrm{~min}$, in the presence of cycloheximide to prevent further protein synthesis, under control conditions (lane a) or with $1 \mu \mathrm{M}$ thapsigargin (lane b). Incorporated radiolabel was detected using a PhosphorScreen and a Molecular Dynamics Phosphorlmager. The positions of $\alpha$-casein and the $\beta / \gamma$-casein doublet are indicated. In some experiments the incorporation into $\alpha$-casein was greater than that into $\beta / \gamma$-casein, as seen previously [22].

cells, we examined the time course of secretion of $\left[{ }^{35}\right.$ S $]$ methionine pulse-labelled proteins from the cells. Under these conditions casein secretion was slowed and continued for up to $150 \mathrm{~min}$ (Figure 7). The data in Figure 7 additionally show that casein secretion was not inhibited at any time point by ionomycin/ EGTA treatment.

\section{DISCUSSION}

We have examined the effects of lumenal $\mathrm{Ca}^{2+}$ depletion by $\mathrm{Ca}^{2+}$ ATPase inhibitors and treatment with ionomycin/EGTA on casein synthesis, phosphorylation and secretion. Both thapsigargin and $\mathrm{tBHQ}$ produced only a transient rise in the cytosolic $\mathrm{Ca}^{2+}$ concentration when tested in the presence of external $\mathrm{Ca}^{2+}$, indicating that their major effect on lactating mammary cells was mobilization of stored $\mathrm{Ca}^{2+}$ without any sustained activation of $\mathrm{Ca}^{2+}$ entry as occurs in certain other cell types [33,34]. The finding that the rises in cytosolic $\mathrm{Ca}^{2+}$ were transient would argue against long-term effects of the inhibitors being due to elevation of cytosolic $\mathrm{Ca}^{2+}$ rather than depletion of lumenal $\mathrm{Ca}^{2+}$. In addition, treatment with ionomycin in the presence of EGTA also produced a transient elevation of cytosolic $\mathrm{Ca}^{2+}$, and under these conditions we would expect all lumenal $\mathrm{Ca}^{2+}$ pools to be depleted.

Treatment with thapsigargin, tBHQ or ionomycin/EGTA resulted in each case in a substantial inhibition of protein synthesis based on a decrease in $\left[{ }^{35} \mathrm{~S}\right]$ methionine incorporation. This was seen as a general depression in radiolabel incorporation
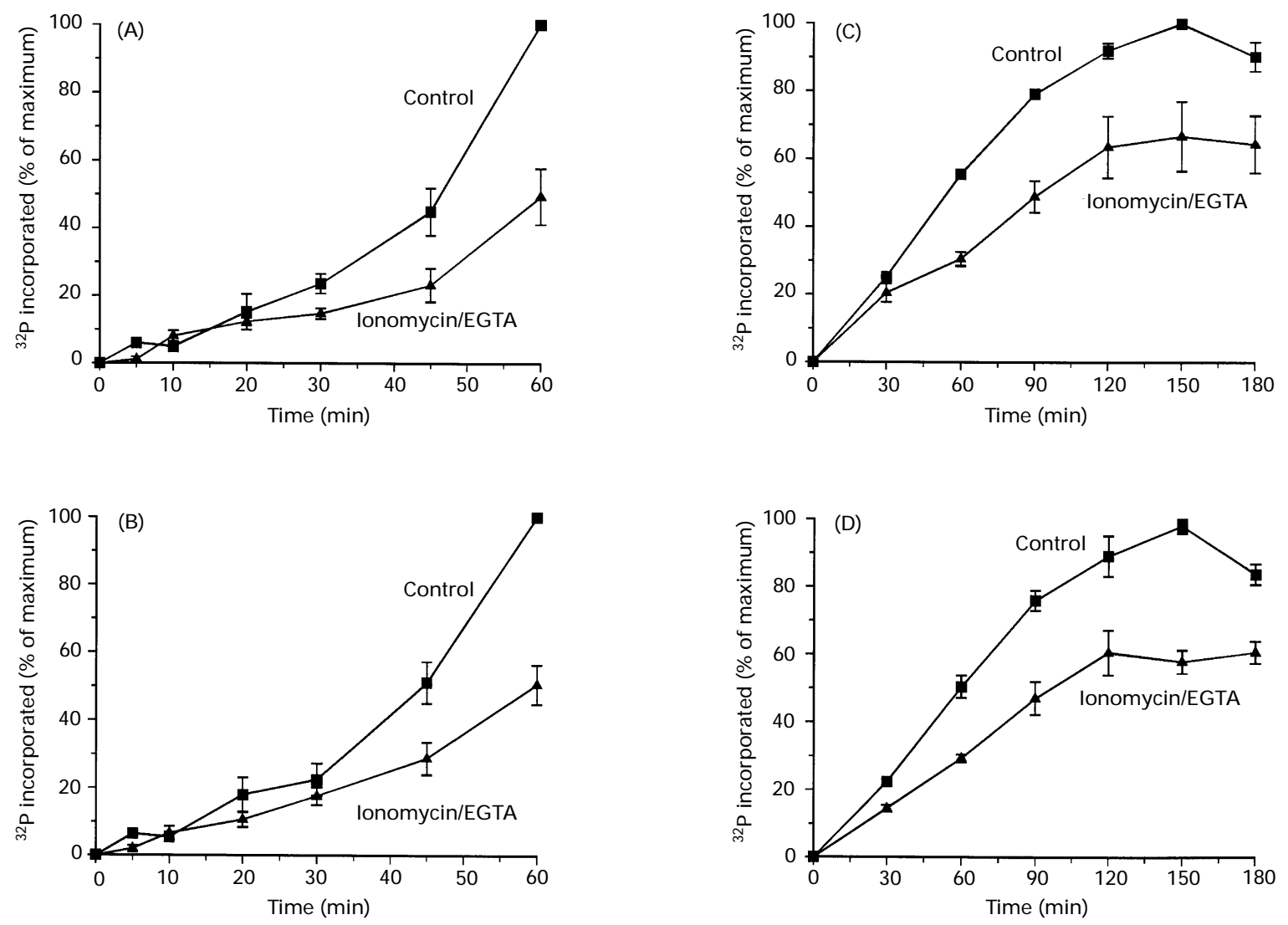

Figure 6 Effects of $\mathrm{Ca}^{2+}$ depletion by treatment with ionomycin/EGTA on the early and late phases of casein phosphorylation in lactating mouse mammary cells

Isolated acini were incubated with [ $\left.{ }^{32} \mathrm{P}\right] \mathrm{P}_{\mathrm{i}}$ for various times in the presence of $100 \mu \mathrm{g} / \mathrm{ml}$ cycloheximide to block protein synthesis and with or without $10 \mu \mathrm{g} / \mathrm{ml}$ ionomycin and $2 \mathrm{mM}$ EGTA. Samples were analysed on duplicate SDS/polyacrylamide gels and ${ }^{32} \mathrm{P}$ incorporation was detected using a PhosphorScreen and quantified using a Molecular Dynamics Phosphorlmager and Image Quant software. In order to allow pooling of data from separate experiments, the data are expressed as percentages of the maximum value obtained. The data shown (means \pm S.E.M.) are from short time courses (A, B; $n=6$ from three cell batches) or longer time courses $(\mathbf{C}, \mathbf{D} ; n=4$ from two cell batches) and give quantification for $\alpha$-casein $(\mathbf{A}, \mathbf{C})$ and for $\beta / \gamma$-casein $(\mathbf{B}, \mathbf{D})$. 


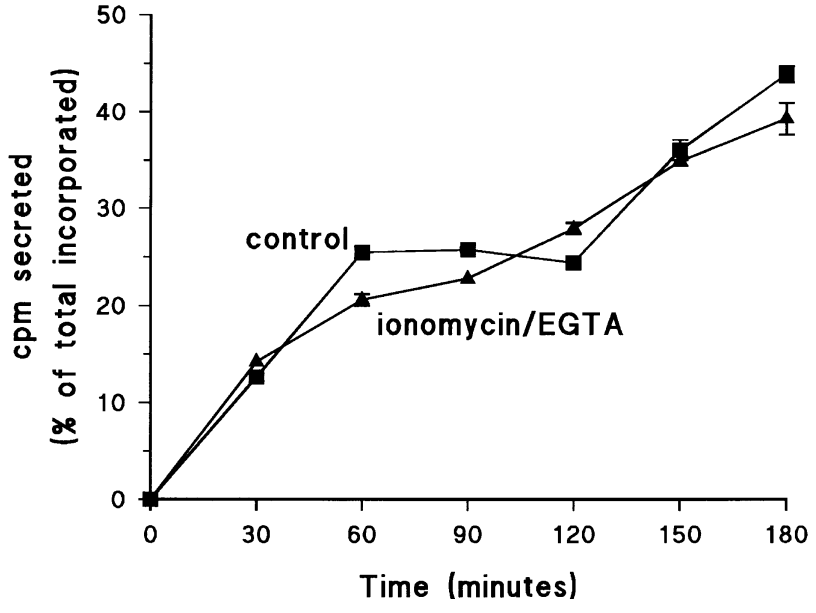

Figure 7 Time course of protein secretion in the presence of cycloheximide, and effect of ionomycin/EGTA

Isolated acini from lactating mammary glands were pulse-labelled with ${ }^{35}$ S]methionine for $1 \mathrm{~h}$, washed and then protein secretion was monitored during the chase periods from analysis of incorporation into trichloroacetic acid-precipitable protein released into the medium. The cells were incubated during the chase period in the presence of $100 \mu \mathrm{g} / \mathrm{ml}$ cycloheximide with or without $10 \mu \mathrm{M}$ ionomycin/2 $\mathrm{mM}$ EGTA. Data shown are means \pm S.E.M. $(n=4)$.

into all synthesized proteins, which are predominantly the secreted caseins $[28,29]$. These data are consistent with earlier work using explants of rabbit mammary gland which showed that inclusion of EGTA in the culture medium resulted in inhibition of protein synthesis [35]. This earlier study did not, however, allow discrimination between the depletion of cytosolic or lumenal $\mathrm{Ca}^{2+}$. In cells treated with thapsigargin or $\mathrm{tBHQ}$, changes in the polysome profile with a loss of polysomes and an increase in the size of the $80 \mathrm{~S}$ monosome peak suggested that the inhibition of protein synthesis was likely to be due to an effect on initiation of translation. This is in agreement with the effects of lumenal $\mathrm{Ca}^{2+}$ depletion in other cell types [6-9]. Thapsigargin, tBHQ and treatment with ionomycin/EGTA had no effect on the constitutive secretion of pre-synthesized caseins. In studies on other secretory proteins, variable effects of $\mathrm{Ca}^{2+}$ depletion on secretion have been observed. Notably, in HepG2 cells the secretion of $\alpha_{1}$-antitrypsin is inhibited following thapsigargin treatment but secretion of albumin is unaffected [7]. Since caseins bind $\mathrm{Ca}^{2+}$, and $\mathrm{Ca}^{2+}$ is required for the stability of the casein micelle, it might be expected that $\mathrm{Ca}^{2+}$ depletion would impair the transit of these proteins through the secretory pathway, but the data presented here show that this did not appear to be the case.

Active $\mathrm{Ca}^{2+}$ uptake occurs into both ER and Golgi vesicles from lactating mammary cells [14-17]. Uptake of $\mathrm{Ca}^{2+}$ into the Golgi cisternae could be necessary to allow accumulation of $\mathrm{Ca}^{2+}$ in the forming secretory vesicles for secretion of $\mathrm{Ca}^{2+}$, or it might have additional functions in the Golgi cisternae. Intralumenal $\mathrm{Ca}^{2+}$ is required for the normal processing of glycosylated secretory proteins $[6,7]$, and $\mathrm{Ca}^{2+}$ or other bivalent cations are required for maximal casein kinase activity in vitro $[23,25,26]$. Using this assay we have previously shown that treatment of lactating mammary cells with brefeldin A, which causes collapse of cis-Golgi cisternae into the ER, results in inhibition of the phosphorylation of $\beta$-and $\gamma$-caseins but not of $\alpha$-casein [22]. These results indicate that phosphorylation of $\alpha$-casein was likely to occur normally in the ER or cis-Golgi, whereas that of $\beta$ - and $\gamma$-caseins would occur predominantly in trans-Golgi cisternae or later post-Golgi compartments. Other secretory proteins have been reported to be phosphorylated in one or other of these locations depending on the particular protein $[21,36]$. Treatment with thapsigargin had no effect on the extent of ${ }^{32} \mathrm{P}$ incorporation into $\alpha$-, $\beta$ - or $\gamma$-caseins during a $30 \mathrm{~min}$ incubation. It is not known whether the mammary Golgi ATPase is sensitive to thapsigargin, and one possibility was that thapsigargin did not lead to depletion of $\mathrm{Ca}^{2+}$ from Golgi cisternae. A requirement for lumenal $\mathrm{Ca}^{2+}$ for an early phase of casein phosphorylation was ruled out, however, by the observation that treatment with ionomycin/EGTA also failed to significantly inhibit phosphorylation over a 30 min incubation, and ionomycin would be expected to act on all intracellular membranes and deplete all lumenal $\mathrm{Ca}^{2+}$ stores. In longer incubations, however, it was apparent that a second and more extensive phase of casein phosphorylation occurred which continued for up to $150 \mathrm{~min}$ of incubation and that this later phase of phosphorylation was partially inhibited by treatment with ionomycin/EGTA. This inhibitory effect was not on the rate of phosphorylation but on the extent of phosphorylation, as a new lower plateau of phosphorylation was observed with ionomycin/EGTA. The reduced phosphorylation of caseins at later times is unlikely to be a consequence of reduced cellular ATP levels, since this would be expected to result in a reduction in the rate rather than the extent of phosphorylation. In addition, under the conditions used (cycloheximide present), secretion, which is ATP-dependent [37], continued over the same time course and was unaffected by ionomycin/EGTA. One explanation for the two phases of casein phosphorylation and the differential effects of $\mathrm{Ca}^{2+}$ depletion would be the presence of two casein kinases differing in $\mathrm{Ca}^{2+}$ sensitivity, with the $\mathrm{Ca}^{2+}$-independent kinase acting at an earlier stage of the secretory pathway than the $\mathrm{Ca}^{2+}$-dependent kinase. Independent evidence in favour of this explanation comes from earlier work which demonstrated two biochemically distinct casein kinase activities in bovine mammary gland Golgi vesicles, one of which was $\mathrm{Ca}^{2+}$-independent and the other $\mathrm{Ca}^{2+}$-dependent [38]. Functional dissection of the Golgi complex by treatment of mouse mammary cells with brefeldin A has also suggested the possible presence of two distinct casein kinases [29]. The membrane-associated intralumenal casein kinases have yet to be purified, and further molecular characterization of these kinases and demonstration of their exact intracellular localization will be required in order to test this interpretation.

In conclusion, $\mathrm{Ca}^{2+}$ within the $\mathrm{ER}$ is clearly required to maintain the rates of synthesis of secretory proteins in lactating mammary cells. Lumenal $\mathrm{Ca}^{2+}$ is not required, however, for the constitutive secretion of the caseins. The significance of the role of $\mathrm{Ca}^{2+}$ in the maintenance of the casein micellar structure is unclear, but a high lumenal $\mathrm{Ca}^{2+}$ concentration is not essential for casein transit through the secretory pathway. The active uptake of $\mathrm{Ca}^{2+}$ into the Golgi cisternae of lactating mammary cells is also likely to be required to allow accumulation of $\mathrm{Ca}^{2+}$ for its secretion, and in addition for a late phase of casein phosphorylation.

This work was supported by a Wellcome Trust Veterinary Clinical Training Award to J.S.D.

\section{REFERENCES}

1 Balch, W. E. (1989) J. Biol. Chem. 264, 16965-16968

2 Burgoyne, R. D. and Morgan, A. (1993) Biochem. J. 293, 305-316

3 Sambrook, J. F. (1990) Cell 61, 197-199

4 Berridge, M. J. (1993) Nature (London) 361, 315-325 
5 Chandra, S., Kable, E. P. W., Morrison, G. H. and Webb, W. W. (1991) J. Cell Sci. 100, 747-752

6 Chin, K.-V., Cade, C., Brostrom, C.-0., Galuska, E. M. and Brostrom, M. A. (1987) J. Biol. Chem. 262, 16509-16514

7 Wong, W. L., Brostrom, M. A., Kuznetsov, G., Gmitter-Yellen, D. and Brostom, C. 0. (1993) Biochem. J. 289, 71-79

8 Prostko, C. R., Dholakia, J. N., Brostrom, M. A. and Brostrom, C. O. (1995) J. Biol. Chem. 270, 6211-6215

9 Srivastava, S. P., Davies, M. V. and Kaufmann, R. J. (1995) J. Biol. Chem. 270 16619-16624

10 Wileman, T., Kane, L. P., Carson, G. R. and Terhorst, C. (1991) J. Biol. Chem. 266, 4500-4507

11 Booth, C. and Koch, G. L. E. (1989) Cell 59, 729-737

12 Ivessa, N. E., De Lemos-Chiarandini, C., Gravotta, D., Salatini, D. and Kriebich, G. (1995) J. Biol. Chem. 270, 25960-25967

13 Yoshimoto, A., Nakanishi, K., Anzai, T. and Komine, S. (1990) Cell Biochem. Struct. 8, 191-198

14 West, D. W. (1991) Biochim. Biophys. Acta 693, 374-386

15 Virk, S. S., Kirk, C. J. and Shears, S. B. (1985) Biochem. J. 226, 741-748

16 Bingham, E. W., McGranaghan, M. B., Wickham, E. D., Leung, C. T. and Farrell, H. M. (1992) Ann. N. Y. Acad. Sci. 671, 418-420

17 Clegg, R. A. and West, D. W. (1991) Biochem. Soc. Trans. 19, S194

18 Aoki, T., Umenda, T. and Kako, Y. (1992) Biosci. Biotech. Biochem. 56, 1878-1879

19 Holt, C., Davies, D. T. and Law, A. J. R. (1986) J. Dairy Res. 53, 557-572

20 Bingham, E. W., Farrell, H. M. and Basch, J. J. (1972) J. Biol. Chem. 247, 8193-8194

21 Capusso, J. M., Keenan, T. W., Abeijon, C. and Hirschberg, C. B. (1989) J. Biol. Chem. 264, 5233-5240
22 Turner, M. D., Handel, S. E., Wilde, C. J. and Burgoyne, R. D. (1993) J. Cell Sci. 106, 1221-1226

23 West, D. W. and Clegg, R. A. (1984) Biochem. J. 219, 181-187

24 Varro, A., Henry, J., Vaillant, C. and Dockray, G. J. (1994) J. Biol. Chem. 269 20764-20770

25 Rosa, P., Mantovani, S., Rosboch, R. and Huttner, W. B. (1992) J. Biol. Chem. 267, 12227-12232

26 Bingham, E. W. and Farrell, H. M. (1974) J. Biol. Chem. 249, 3647-3651

27 Bingham, E. W. and Groves, M. L. (1979) J. Biol. Chem. 254, 4510-4515

28 Turner, M. D., Rennison, M. E., Handel, S. E., Wilde, C. J. and Burgoyne, R. D. (1992) J. Cell Biol. 117, 269-278

29 Rennison, M. E., Handel, S. E., Wilde, C. J. and Burgoyne, R. D. (1992) J.Cell Sci. 102, 239-247

30 Rennison, M. E., Kerr, M., Addey, C. V. P., Handel, S. E., Turner, M. D., Wilde, C. J. and Burgoyne, R. D. (1993) J. Cell Sci. 106, 641-648

31 Thastrup, O., Dawson, A,P., Scharff, O., Foder, B., Cullen, P. J., Probak, B. K., Bjerrum, P. J., Christensen, S. B. and Hanley, M. R. (1989) Agents Actions 27, $17-23$

32 Moore, G. A., McConkey, D. J., Kass, G. E. M., O'Brien, P. J. and Orrenuis, S. (1987) FEBS Lett. 224, 331-336

33 Robinson, I. M., Cheek, T. R. and Burgoyne, R. D. (1992) Biochem. J. 288, 457-463

34 Takemura, H., Hughes, A. R., Thastrup, O. and Putney, J. W. (1989) J. Biol. Chem. 264, 12266-12271

35 Wilde, C. J., Hasan, H. R., White, D. A. and Mayer, R. J. (1981) Biochem. Biophys. Res. Commun. 103, 934-942

36 Varro, A. and Dockray, G. J. (1993) Biochem. J. 295, 813-819

37 Turner, M. D., Wilde, C. J. and Burgoyne, R. D. (1992) Biochem. J. 286, 13-15

38 Brooks, C. L. (1989) FEBS Lett. 243, 385-388

Received 8 December 1995/13 March 1996; accepted 21 March 1996 